\title{
Effect of NPS Fertilizers Application and Irrigation System on Growth and Yield of Snap Bean (Phaseolus vulgaris I): A Review
}

\author{
Melkamu Hinsermu \\ Ethiopian Institute of Agricultural Research, Melkassa Agricultural Research Center
}

\begin{abstract}
Snap bean (Phaseolus vulgaris L.) is the most important vegetable crop for export and local market. Even though snap bean is many important, the yield haven been obtained is low mainly due to decline soil fertility and irrigation system problems. Now a day's Ethiopian soils not only limiting phosphorus and nitrogen nutrients, but also sulfur is a major problem. Water stress that reduced yield and pod quality of snap bean. Irrigation schedule is very crucial to make the most efficient use of irrigation system to avoid excessive water and shortage problem. Snap bean required high amount of nitrogen fertilizer, due to its weak fixation capacity of atmospheric nitrogen. Application of nitrogen at $150 \mathrm{~kg} \mathrm{~N} \mathrm{ha}^{-1}$ increased growth and pod yield parameters snap bean. The optimum rate of phosphorus at $21 \mathrm{~kg} \mathrm{P} \mathrm{ha}^{-1}$ was applied at the time of seeding in the form of triple super phosphate for snap bean production in Ethiopia. Application of sulfur at $30 \mathrm{~kg} \mathrm{~S} \mathrm{ha}^{-1}$ increased nitrogen, phosphorus and sulfur nutrient availability. Today there is lack of information on snap bean production in Ethiopia, especially NPS fertilizers application and under different irrigation system. Snap bean producers needs optimum rate of NPS fertilizers application and with different irrigation system, so research institutions and higher learning educations generate information to snap bean producers in Ethiopia at site-specific.
\end{abstract}

Keywords: Fertilizers, Irrigation System, Snap bean, Yield

DOI: $10.7176 / \mathrm{JBAH} / 9-19-05$

Publication date:October $31^{\text {st }} 2019$

\section{Introduction}

Snap bean (Phaseolus vulgaris L.) comprises a group of common bean that has been selected for succulent pods with reduced fiber primarily grown for its young edible and fleshly pods (Myer and Baggett, 1999; Getachew, 2006). It is the most important vegetable crop which is rich in protein, carbohydrates, calcium, vitamins and amino acids. It is also the most important vegetables crop have been exported from developing countries and several African countries have focused on exporting snap beans to high-value European markets (Ghonimy et al., 2009).

In Ethiopia, the production of snap beans started by large commercial farmers in the early 1970s. It is mainly produced in upper awash and the lake region in eastern Shoa (EHPEA, 2011). Its' production in Ethiopia has increased from time to time both for export and local markets (Hussein et al., 2015). It is the most important export vegetable crop extensively produced for export with the highest share (94\%) among all vegetables (Lemma et al., 2006; Lemma, 2011). Globally, the yield for snap bean ranges between 8 and $10 \mathrm{t} \mathrm{ha}^{-1}$, with high yields of more than $14 \mathrm{t} \mathrm{ha}^{-1}$ being recorded in China, USA and Latin America (CIAT, 2006). The average pod yield in smallholder farms in eastern and central Africa is low ranging between 4 and $8 \mathrm{t} \mathrm{ha}^{-1}$ (Kimani et al., 2004) due to poor soil fertility and inadequate moisture (Amare and Haile, 1989).

Water stress problems can reduce pod yield about $20 \%$ when water stress persisted for 15 days before blooming, 18-22 days during blooming, or 15 days before ripening. Water stress cause high fiber content in the green pods (Mack et al., 1982). Scheduling water application is very critical to make the most efficient use of irrigation system to avoid excessive water and shortage (Hakan et al., 2008; Mohamed et al., 2012). Other factor declining soil fertility is a major problem in snap bean production areas in eastern Africa including Ethiopia. Previously, Ethiopian smallholder farmers were limited to DAP and urea, fertilizers that only delivered $\mathrm{N}$ and $\mathrm{P}$ nutrients (Khalid, 2013). Farmers and farmer corporative union have already requested that the government make the new blended fertilizers more available (MOA, 2014). Soil tests show that many croplands lack of other essential nutrients such as sulfur, boron, potassium, zinc, and copper (ATA, 2015).

The $\mathrm{N}$ fertilizer requirement of snap bean is high, due to its weak fixation capacity of atmospheric $\mathrm{N}$ compared to other beans (Feleafel and Mirdad, 2014). In the tropics region, the amount of available P in soils is largely insufficient to meet the demand of beans and thus, P deficiency is prevalent in bean crops (Azmera and Pellegrino, 2017). Snap bean has high demand of sulfur due to production of several protein containing materials and fatty acids. Now, day's S deficiency is becoming widespread throughout the world due to the use of sulfurfree fertilizers, intensive cropping, and use of high-yielding varieties (Alemu et al., 2016). Thus, this review was carried out with the following objectives:

- To review the effect NPS fertilizers application on growth and yields of snap bean.

- To review the effect of different irrigation system on growth and yield of snap bean. 


\section{Effect of NPS Fertilizers and Irrigation System on Growth and Yield of Snap Bean \\ 2.1. Snap Bean Production}

Suitable production areas of snap bean in Ethiopia have been indicated as the areas with altitude between 10002100 m.a.s.l. Mean maximum and minimum temperature of less than $32^{\circ} \mathrm{C}$ and greater than $10^{\circ} \mathrm{C}$, respectively with a rainfall ranging from 350 to $700 \mathrm{~mm}$ well distributed over 70-90 days (Amare and Haile, 1989). It is grow best in well-drained soils high in organic matter with $\mathrm{pH} 5.5$ to 6.5. They are sensitive to cold and even a slight frost can cause damage. Its' require a continuous supply of moisture, especially during pod set and pod development (Michael and Orzolek, 2002).

\subsection{Effect of NPS Fertilizers Application on Growth and Yield of Snap Bean}

\subsubsection{Effect of nitrogen on growth and yield of snap bean}

Nitrogen requirement of snap bean is high due to lack of NOD genes, hence it does not have effective nodules and this makes them poor in symbiotic nitrogen fixing (Kushwaha, 1994). According to Andrea et al. (2008) stated that $\mathrm{N}$ application increased the vegetative growth, fresh and dry weight pods, reproductive parts, and improves pod quality, but the highest $\mathrm{N}$ doses delayed the ripening of snap bean. As $\mathrm{N}$ levels, increases from 0 to $150 \mathrm{~kg} \mathrm{ha}^{-1}$ the growth and yield attributing of snap bean parameters were increased. Application of 100 $\mathrm{kg} \cdot \mathrm{N} \cdot \mathrm{ha}^{-1}$ increased pod yield by 42 and $17 \%$ as compared to the control and rhizobial inoculation, respectively (Table 1) (Hussein et al., 2015). According to Tesfaye (2017) showed that application of $92 / 69 \mathrm{~N} \mathrm{P}_{2} \mathrm{O}_{5} \mathrm{~kg} \mathrm{ha}^{-1}$ gave the highest pod yield (Figure 1). The mineral $\mathrm{N}$ in the soil is mainly nitrate $\left(\mathrm{NO}_{3}{ }^{-}\right)$and to a lesser extent ammonium $\left(\mathrm{NH}^{+}\right)$(Kamanu et al., 2012). Nitrogen deficiency results in stunted, reduction yield and chlorotic leaves in snap bean (Feleafel and Mirdad, 2014).

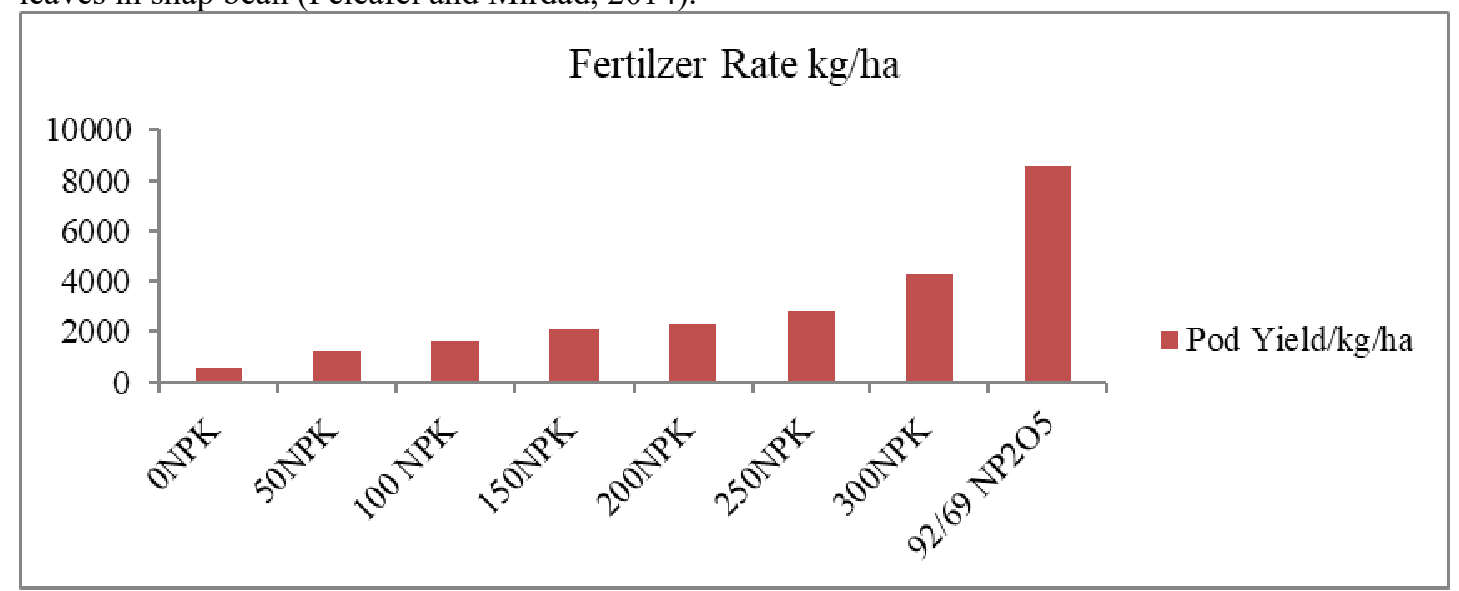

Figure 1. Mean pod yield of snap bean as affected by different rates of fertilizer application

Source: Tesfaye, 2017

Table 1. Pod marketable yield, length, diameter, titratable acidity and total soluble solids (TSS) of snap bean affected by nitrogen treatment and cultivars.

\begin{tabular}{lrcccc}
\hline \multicolumn{1}{c}{ N. Treatment } & $\begin{array}{c}\text { Marketable } \\
\text { yield }(\mathrm{t} / \mathrm{ha})\end{array}$ & $\begin{array}{c}\text { Pod length } \\
(\mathrm{mm})\end{array}$ & $\begin{array}{c}\text { Pod diameter } \\
(\mathrm{mm})\end{array}$ & $\begin{array}{c}\text { Titratable } \\
\text { acidity }(\%)\end{array}$ & $\begin{array}{c}\text { TSS } \\
\left({ }^{\mathrm{o}} \text { Brix }\right)\end{array}$ \\
\hline $100 \mathrm{~kg} \mathrm{~N} \mathrm{ha}^{-1}$ & $20.54^{\mathrm{a}}$ & 125.0 & 7.56 & $0.0769^{\mathrm{a}}$ & 5.54 \\
Rhizobium etli $(\mathrm{HB}) 429)$ & $16.92 \mathrm{~b}$ & 122.0 & 7.49 & $0.0747^{\mathrm{a}}$ & 5.50 \\
Zero N & $14.39^{\mathrm{c}}$ & 120.2 & 7.38 & $0.0701^{\mathrm{b}}$ & 5.46 \\
Cultivar & & & & \\
Andante & $11.70 \mathrm{c}$ & $106.4^{\mathrm{e}}$ & $6.01^{\mathrm{e}}$ & $0.0765^{\mathrm{a}}$ & $5.44^{\mathrm{b}}$ \\
Boston & $17.94^{\mathrm{b}}$ & $123.1^{\mathrm{bc}}$ & $7.11^{\mathrm{d}}$ & $0.0768^{\mathrm{a}}$ & $5.41^{\mathrm{b}}$ \\
Contender Blue & $16.94^{\mathrm{b}}$ & $112.8^{\mathrm{d}}$ & $7.38^{\mathrm{cd}}$ & $0.0747^{\mathrm{ab}}$ & $5.47^{\mathrm{ab}}$ \\
Lomami & $18.14^{\mathrm{ab}}$ & $122.7^{\mathrm{c}}$ & $7.44^{\mathrm{cd}}$ & $0.0775^{\mathrm{a}}$ & $5.51^{\mathrm{ab}}$ \\
Melkassa 1 & $20.60^{\mathrm{a}}$ & $125.8^{\mathrm{bc}}$ & $8.68^{\mathrm{a}}$ & $0.0668^{\mathrm{c}}$ & $5.49^{\mathrm{ab}}$ \\
Melkassa 3 & $16.95^{\mathrm{b}}$ & $133.8^{\mathrm{a}}$ & $8.32^{\mathrm{b}}$ & $0.0726^{\mathrm{abc}}$ & $5.56^{\mathrm{a}}$ \\
Paulista & $17.98^{\mathrm{b}}$ & $126.5^{\mathrm{bc}}$ & $7.36^{\mathrm{cd}}$ & $0.0700^{\mathrm{bc}}$ & $5.57^{\mathrm{a}}$ \\
Volta & $18.00 \mathrm{~b}$ & $128.1^{\mathrm{b}}$ & $7.48^{\mathrm{c}}$ & $0.0763^{\mathrm{a}}$ & $5.56^{\mathrm{a}}$ \\
\hline
\end{tabular}

Means followed by the different letters in a treatment grouping column differ significantly based on LSD, $P<0.05$

Source: Hussein et al., 2015 


\subsubsection{Effect of phosphorus on growth and yield of snap bean}

Phosphorus plays a vital role in protein synthesis, photosynthesis, respiration, energy reactions, genetic transfer, cell division and development of new tissue (Raghothama and Karthikeyan, 2005; Ali et al., 2013). It is also essential as a component on structure of DNA, RNA, ATP, ADP, NADPH, which act on growth and development of vegetative and generative organs: flower, fruit and pods (Yadav et al., 2014). Plants absorb P mostly in soluble $\left(\mathrm{H}_{2} \mathrm{PO}_{4}^{-}\right.$and $\left.\mathrm{HPO}_{4}{ }^{-2}\right)$ forms (Raghothama and Karthikeyan, 2005). The phosphate fertilization of soils has always been important, because it fixed as water insoluble $\mathrm{Fe}$ and $\mathrm{Al}$ phosphates in acidic soils or $\mathrm{Ca}$ and Mg phosphate in alkaline soils (Singh and Kapoor, 1994).

According to Rafat and Sharifi (2015) revealed that application of $\mathrm{P}$ at $50 \mathrm{~kg} \mathrm{P} \mathrm{ha} \mathrm{k}^{-1}$ increased plant height, pod length, pods number plant ${ }^{-1}$ and pod yield (Table 2). Snap beans applied $100 \mathrm{~kg} \mathrm{P}^{-1}$ produced $71 \%$ greater pod yield than controls (Faegheh and Hashem, 2015). The recommended rate of P $21 \mathrm{~kg} \mathrm{P} \mathrm{ha}^{-1}$ was applied at the time of seeding in the form of TSP for snap bean production in Ethiopia (Hussein et al., 2015).

Table 2. Effect of phosphorus fertilizers on growth, yield and yield components

\begin{tabular}{lcccccc}
\hline $\mathrm{P}\left(\mathrm{kg} \mathrm{ha}^{-1}\right)$ & $\mathrm{PH}(\mathrm{cm})$ & PL $(\mathrm{cm})$ & NPP & $\begin{array}{c}\text { PY } \\
\left(\mathrm{kg} \mathrm{ha}^{-1}\right)\end{array}$ & $\begin{array}{c}\text { BY } \\
\left(\mathrm{kg} \mathrm{ha}^{-1}\right)\end{array}$ & HI $(\%)$ \\
\hline 0 & $26.67 \mathrm{c}$ & $14.30 \mathrm{~b}$ & $17.00 \mathrm{~d}$ & $3833.33 \mathrm{c}$ & $6760.00 \mathrm{c}$ & $56.71 \mathrm{~b}$ \\
25 & $29.00 \mathrm{bc}$ & $15.67 \mathrm{~b}$ & $19.00 \mathrm{bc}$ & $4043.33 \mathrm{~b}$ & $6946.67 \mathrm{a}$ & $58.21 \mathrm{~b}$ \\
50 & $33.00 \mathrm{a}$ & $18.37 \mathrm{a}$ & $21.00 \mathrm{a}$ & $4310.00 \mathrm{a}$ & $6920.00 \mathrm{ab}$ & $62.19 \mathrm{a}$ \\
75 & $30.67 \mathrm{ab}$ & $16.17 \mathrm{ab}$ & $20.00 \mathrm{ab}$ & $4303.33 \mathrm{a}$ & $6823.33 \mathrm{bc}$ & $63.17 \mathrm{a}$ \\
100 & $27.67 \mathrm{bc}$ & $15.17 \mathrm{~b}$ & $17.67 \mathrm{~cd}$ & $3923.33 \mathrm{bc}$ & $6300.00 \mathrm{~d}$ & $62.29 \mathrm{a}$ \\
\hline LSD $(5 \%)$ & 3.78 & 2.61 & 1.85 & 147.2 & 100.55 & 2.06 \\
\hline
\end{tabular}

The columns having common letter ( $s$ ) do not differ significantly at $5 \%$ level of significance $P=$ Phosphorus fertilizers. PH Plant height, $P L=$ Pod length, NPP = Number of pods per plant, $P Y=$ Pod yield, BY= Biological yield, $H I=$ Harvest index

Source: (Rafat and Sharifi, 2015)

\subsubsection{Effect of sulfur on growth and yield of snap bean}

Sulfur is one of the essential nutrients for plant growth with crop requirement similar to phosphorus. Its' serves important structural, regulatory and catalytic functions in the context of proteins, and as a major cellular redox buffer in the form of the tri-peptide glutathione and certain proteins such as thioredoxin, glutaredoxin and protein disulfide isomerase. Application of sulfur at $45 \mathrm{~kg} \mathrm{~S}^{-1}$ increased number of fresh and dry nodule weight and nodules plant $^{-1}$ (Figure 2).

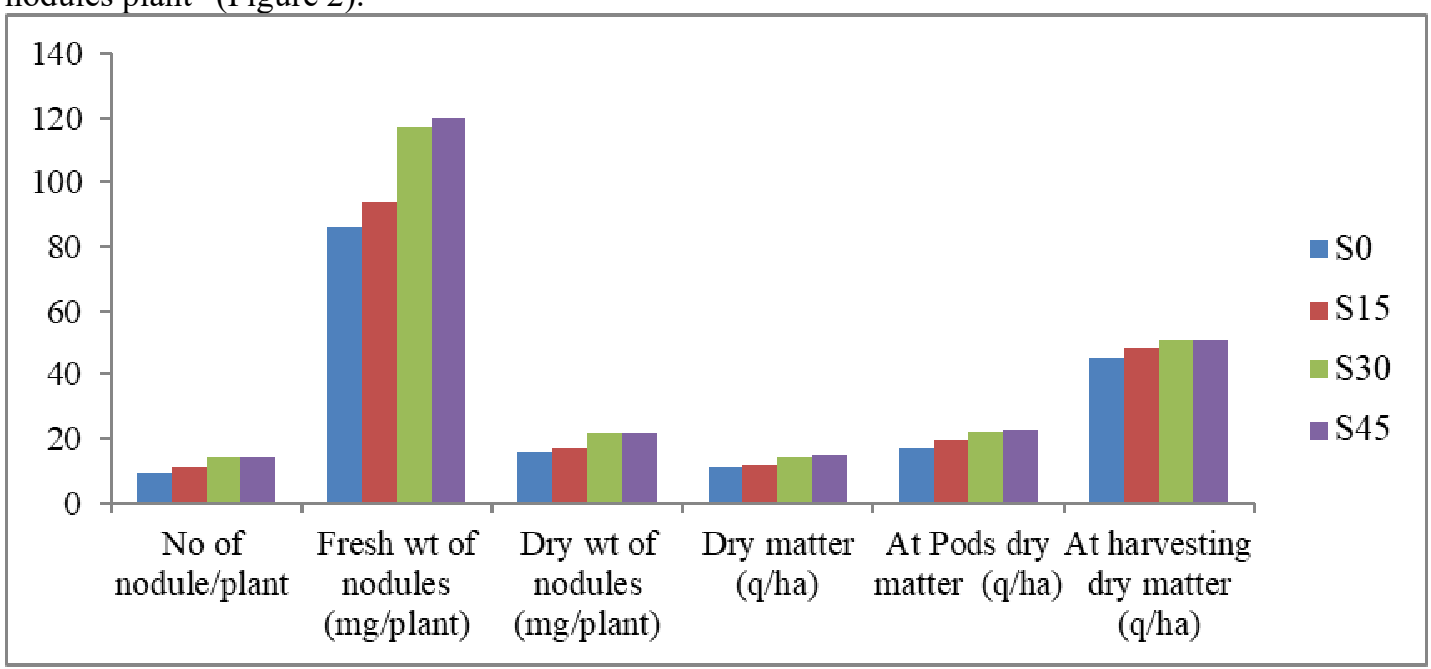

Figure 2. The effect of sulfur application on growth and yield of snap bean (Var. Contender)

Source: Mumtaz et al., 2014

Application of sulfur from 0 to $30 \mathrm{~kg} \mathrm{~S} \mathrm{ha}^{-1}$ increased N, P, K, S, and B by 6.43, 22.22, 26.92, 18.30 and 46.53 in pods, respectively (Mumtaz et al., 2014) (Figure 3). Application of gypsum at the rate of $60 \mathrm{Kg} \mathrm{ha}^{-1}$ produced significantly higher pod length (Singh and Aggarwal, 1998). Although the dry weight of nodules at higher levels of $\mathrm{S}$ showed a tendency to increase, but this was not significantly beyond $20 \mathrm{~kg} \mathrm{~S} \mathrm{ha}^{-1}$ (Ganeshhamurthy and Reddy, 2000). The available form of sulfur in plant is sulfate $\left(\mathrm{SO}_{4}{ }^{-2}\right.$ ) (Rob et al., 2013). Sulfur is immobile in plants, does not readily move from old to new growth, leads chlorosis of younger leaves and at later stages; leaves show necrotic symptoms and die (Khan and Mazid, 2011). 


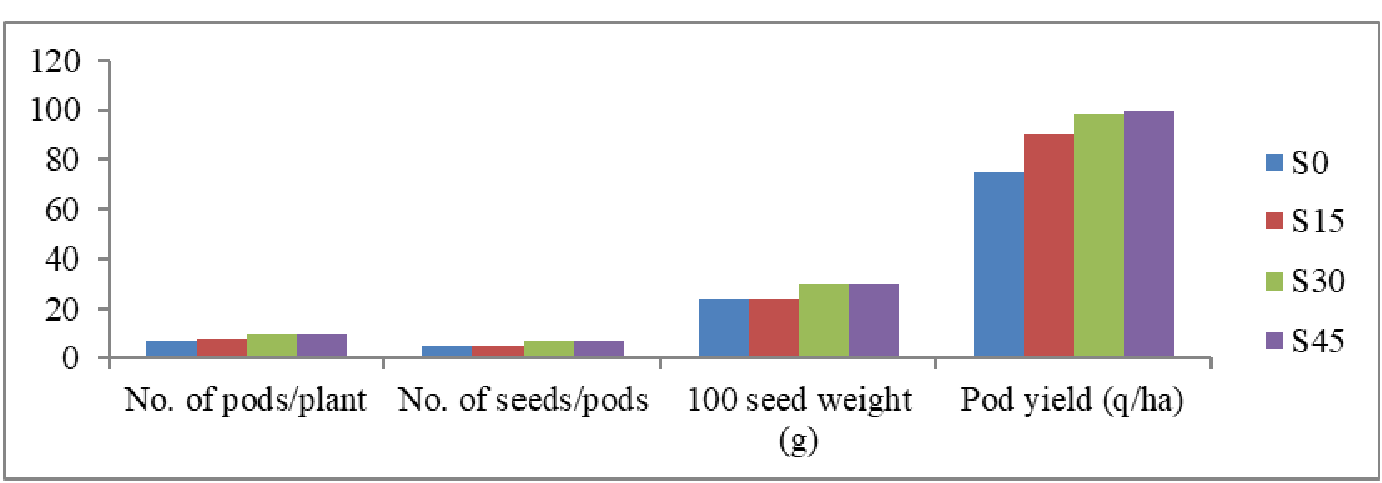

Figure 3. The effect of sulfur fertilizer on yield and yield attributing characters of snap bean Source: Mumtaz et al., 2014

\subsection{Effect of Irrigation System on Growth and Yield of Snap Bean}

According to FAO (2002) declared that to choose an irrigation method, the farmer must know the advantages and disadvantages of the various methods. The suitability of the various irrigation methods, i.e. surface and pressurized irrigation depends mainly on the following factors: natural conditions, type of crop, type of technology, previous experience with irrigation, required labor inputs, costs and benefits.

\subsubsection{Furrow Irrigation}

Traditionally, farmers in the central rift valley of Ethiopia have been using the most conventional surface irrigation system; most commonly furrow irrigation system (Abdulaziz, 2015). This method is best suited to deep, moderately permeable soils and uniform relatively flat slopes. It requires smaller initial investment compared to drip irrigation systems (Michael, 1997). Furrows provide better on-farm water management flexibility under many surface irrigation conditions. The discharge per unit width of the field substantially reduced and topographical variations can be more severe (Walker, 1989).

Table 3. Effect of different irrigation systems and irrigation regimes on vegetative growth characters of beans

\begin{tabular}{ccccccccc}
\hline Treatments & \multicolumn{9}{c}{ Growth characters } & \multicolumn{3}{c}{ Dry weight $(\mathrm{gm})$} \\
\hline & PH $(\mathrm{cm})$ & BNP & LNP & PNP & LA $(\mathrm{cm})$ & Stem & Leaves & Total plant \\
\hline SD & $46.89 \mathrm{a}$ & $8.81 \mathrm{a}$ & $25.03 \mathrm{a}$ & $3.39 \mathrm{~b}$ & $2592 \mathrm{~b}$ & $4.74 \mathrm{a}$ & $6.10 \mathrm{a}$ & $13.08 \mathrm{a}$ \\
SSD & $47.99 \mathrm{a}$ & $8.38 \mathrm{~b}$ & $23.23 \mathrm{a}$ & $3.62 \mathrm{a}$ & $2629 \mathrm{a}$ & $4.99 \mathrm{a}$ & $5.89 \mathrm{a}$ & $13.16 \mathrm{a}$ \\
GP & $46.33 \mathrm{a}$ & $8.13 \mathrm{c}$ & $21.33 \mathrm{c}$ & $3.27 \mathrm{~b}$ & $2007 \mathrm{c}$ & $3.58 \mathrm{c}$ & $3.95 \mathrm{~b}$ & $9.19 \mathrm{~b}$ \\
FI & $42.72 \mathrm{~b}$ & $8.09 \mathrm{c}$ & $18.67 \mathrm{~d}$ & $2.32 \mathrm{c}$ & $1754 \mathrm{~d}$ & $4.29 \mathrm{a}$ & $3.93 \mathrm{~b}$ & $8.27 \mathrm{c}$ \\
\hline $100 \%$ ETc & $47.49 \mathrm{a}$ & $8.44 \mathrm{a}$ & $22.75 \mathrm{a}$ & $3.42 \mathrm{a}$ & $2649 \mathrm{a}$ & $4.00 \mathrm{~b}$ & Ns & $11.99 \mathrm{a}$ \\
$80 \%$ ETc & $46.08 \mathrm{~b}$ & $8.33 \mathrm{ab}$ & $21.98 \mathrm{~b}$ & $3.31 \mathrm{a}$ & $2107 \mathrm{~b}$ & $3.79 \mathrm{c}$ & Ns & $10.56 \mathrm{~b}$ \\
$60 \%$ ETc & $44.16 \mathrm{c}$ & $8.30 \mathrm{~b}$ & $21.61 \mathrm{c}$ & $2.71 \mathrm{~b}$ & $1980 \mathrm{c}$ & 4.47 & Ns & 10.22 \\
\hline
\end{tabular}

PH: Plant height, BNP: Branches no per plant, LNP: Leaves per plant, PNP: Pods per plant, LA: Leave area, SD: Surface drip, SSD: subsurface drip, GP: gated pipes, FI: furrow irrigation

Source: El-Noemani et al., 2010

\subsubsection{Drip irrigation}

Drip irrigation is an irrigation method that saves water and fertilizer by allowing water to drip slowly to the roots of plants, either onto the soil surface or directly onto the root zone, through a network of valves, pipes, tubing, and emitters (Sabreen et al., 2014). Compared to sprinkler and furrow irrigation methods (with efficiencies of $60-70 \%$ in high management systems), drip irrigation can achieve 90-95\% efficiency (Isaya, 2001). Its' allows small, but frequent application of water with minimum losses (Taha et al., 2011).

Drip irrigation use in adverse factors, low hazards, and conservation of proper soil structure, possible control of pests and weeds and decreasing the adverse effect of salinity. However, the disadvantages of this system include increases in capital expenditure, incidents of orifices clogging, incidents of salinity build-up and need for technical handling (Charles, 2007). Snap bean pod diameter was increase with increasing irrigation level to $100 \%$ pan (Abdel-Mawgoud, 2006). The highest values number of branches, number of leaves, leaves area and leaf dry weight were recorded at surface followed by sub-surface drip irrigation (Table 3) (El-Noemani et al., 2010).

\section{Summary and Conclusions}

Snap bean is one of the most important vegetable crop both for export and local market, but the yield is low due to two key abiotic constraints are low soil fertility and water stress. Water stress during the blossom pod set period can cause blossom and pods to drop; resulting to poor pod quality and reduced yield.

Now a day's soil tests show that cropland lacks not only $\mathrm{N}$ and $\mathrm{P}$, but also other essential nutrients such as 
sulfur nutrient. As $\mathrm{N}$ levels increases from control to $150 \mathrm{~kg} \mathrm{~N} \mathrm{ha}^{-1}$ the growth and yield attributing of snap beans parameters were increased. As $\mathrm{P}$ fertilized applied at $21 \mathrm{~kg} \mathrm{P} \mathrm{ha}^{-1}$ gave higher pod yields. The highest pod yield obtained by application of $30 \mathrm{~kg} \mathrm{~S} \mathrm{ha}^{-1}$, which might be due to the cumulative favorable effect of higher number of branches and pods plant ${ }^{-1}$.

Generally, today there is lack of information on snap bean production in Ethiopia, especially NPS fertilizers application and under different irrigation system, so research institution and higher learning education generate information to snap bean producers at site-specific.

\section{References}

Abdel-Mawgoud, A.M.R. 2006. Growth, yield and quality of green bean (Phaseolus vulgaris L.) in response to irrigation and compost applications. Journal of Applied Science Research, 2(7):443-450.

Abdulaziz Husen. 2015. Comparison of drip and furrow irrigation methods under deficit irrigation and mulching on growth, yield and water productivity of common beans (Phaseolus vulgaris L) in central rift Valley of Ethiopia. M.Sc. Thesis, Haramaya University, Haramaya. Agronomy, 29, 146-149.

Alemu Lelago, Tekalign Mamo, Wassie Haile \& Hailu Shiferaw. 2016. Assessment and mapping of status and spatial distribution of soil macronutrients in Kambata Tembaro Zone, Southern Ethiopia. Advanced Plants Agri. Res., 4(4):1-14.

Ali, A.G., Seyyed, H.M., Ahmad, M.G. \& Idupulapati, R. 2013. Effects of water stress on leaves and seeds of bean (Phaseolus vulgaris L.). Turkish Journal of Field Crops, 18(1), 73-77.

Amare Abebe and Haile Kefene. 1989. Country reports of Eastern Ethiopia. In: Proceedings of a workshop on bean varietal improvement in Africa. 30 January to 2 February, 1989, pp. 110-121, Maseru, Lesotho, CIAT.

Andrea, B.K., Imre, V. \& Rita, K. 2008. Growth and yield responses garden bean (Phaseolus vulgaris 1.) to nitrogen and sulfur fertilization. Allele Universităţii din Oradea, Fascicula: Protection Mediului, 13:69- 75.

ATA (Agricultural Transformation Agency). 2015. Soil Fertility Mapping and Fertilizer Recommendation in Ethiopia: Update of EthioSIS project and status of fertilizer blending plants.

Azmera Walche \& Pellegrino Conte. 2017. Elucidating the role of phosphorous on growth performance and yield components of haricot bean (Phaseolus vulgaris L.) at Arba Minch, Southern, Ethiopia. Int. J. Agric. Res. Rev. 5(1):579-587.

Charles, M. 2002. Fertigation chemical. Fertigation. 295 p.

CIAT. 2006. Snap beans for income generation by small farmers in east Africa: Highlights CIAT in Africa, No.1.

EHPEA. 2011. Assessment of development potentials and investment options in the export- oriented fruit and vegetable sector. Ethiopian Horticultural Development Agency.

El-Noemani, A.A., El-Zeiny, H.A., El-Gindy, A.M., El-Sahhar, E.A. \& El-Shawadfy, M.A. 2010. Performance of some bean varieties under different irrigation systems and regimes. Aus. J. Bas. and Appli. Sci. 4(12): 6185-6196.

FAO. 2002. Deficit irrigation practices. Water Reports No. 22. FAO, Rome, Italy.

Feleafel, M.N. \& Mirdad, Z.M. 2014. Influence of organic nitrogen on the snap bean grown in sandy soil. Int. $J$. Agric. Biol. 16:65-72.

Ganeshamurthy, A.N., \& Reddy, K.S. 2000. Effect of integrated, use of farmyard manure and sulfur in a soybean and wheat cropping system on nodulation, dry matter production and chlorophyll content of soybean on Swell-Shrink soils in Central India. J. Agri. Cr. Sci.185:91-97.

Getachew Abate. 2006. The market for fresh snap beans. The Strategic Marketing Institute, Working Paper. pp. 6-8.

Ghonimy, M.I., Suliman, A.E., Ibrahim, W.M. \& Abd El Rahman, E.N. 2009. Design of snap bean pods harvesting prototype by stripping. In proceeding paper, 4th Conference on Recent Technologies in Agriculture. Cairo University, Egypt.

Hakan, B., Senih,Y., Serhat, A., Burak, N.C. \& Fusun A. 2008. Effects of deficit irrigation on yield and quality of unheated greenhouse grown green bean. Journal of Food, Agriculture \& Environment, 6 (2):155-159.

Hussein Mohammed Beshir, Frances, L.W., Rosalind B. \& Bunyamin Tar'an. 2015. Response of snap bean cultivars to rhizobium inoculation under dry land Agriculture in Ethiopia. Agronomy, 5, 291-308.

Isaya, V.S. 2001. Drip irrigation: options for smallholder farmers in Eastern and Southern Africa. Published by Sida's Regional Land Management unit, Nairobi, Kenya. Lad, N.G, Patange, M.J. and Dhage, S.J. 2014. Effect of Nitrogen and Phosphorous levels on growth, yield attributing characters, yield and economics of French bean (Phaseolus vulgaris L.) Int. J. Curr. Micro.Biol. App. Sci., 3 (12):822-827.

Kamanu, J.K., Chemining'wa, G.N., Nderitu, J.H. \& Ambuko, J. 2012. Growth, yield and quality response of snap bean (Phaseolus vulgaris L.) plants to different inorganic fertilizers applications in central Kenya. $J$. Appl. Bio. Sci., 55:3944-3952.

Kimani, P.M., Van Rheenen, H., Mathenge, P. \& Ndegwa, A. 2004. Breeding snap beans for smallholder production in East and Central Africa: In Bean Improvement for the Tropics, Annual Report 2004. CIAT, 
Cali, Colombia, Pp. 49-51.

Khan, T.A. \& Mazid, M. 2011. Nutritional significance of sulfur in pulse cropping system. Biology and Medicine, 3 (2):114-133.

Lemma Dessalegn. 2006. Varietal development of major vegetables in the rift valley region. Proceeding of the Inaugural and first Ethiopian horticultural science society (EHSS), 27- 30 March 2006. Addis Ababa, Ethiopia.

Lemma Dessalegn. 2011. Strengthening the development of fruits and vegetable industry in Ethiopia. Abstracts and Program, Third Biennial Conference of Ethiopian Horticultural Science Society (EHSS), 4-5 February 2011. Jimma University College of Agriculture and Veterinary Medicine, Jimma, Ethiopia.

Mack, H.J. \& Varseveld, G.W. 1982. Response of bush snap beans (Phaseolus vulgaris L.) to irrigation and plant density. J. Amer. Soc. Hort. Sci.107:286-290.

Michael, A.M. 1997. Irrigation Theory and Practice (Revised ed.). Vikas publishing house Pvt Ltd, New Delhi.

Michael \& Orzolek. 2002. Agriculture (snap bean production). Northumberland publisher, Pp.1785-1788.

MOA (Minister of Agriculture). 2014. Ethiopia First Ever fertilizer Blending plant inaugurated report.

Mohamed, M., Mohamed, E. \& Amal, L.A. 2012. Response of green bean to pulse surface drip irrigation. Journal of Horticultural Science \& Ornamental Plants, 4 (3):329-334.

Mumtaz, A., Farida, A.G. Najar, G.R. \& Bhat, M.A. 2014. Influence of sulfur and boron supply on nutrient content and uptake of French bean (Phaseolus vulgaris L.) under incept sols of North Kashmir 232 Afr. J. Agric. Res. 9(2): 230-239.

Myers, J.R. \& Baggett. J.R. 1999. Improvement of snap bean. Pp. 289 -329.IN: Singh SP (eds) Common Bean Improvement in the Twenty-first Century Dordrecht: Kluwer.

Rafat, M. \& Sharifi, P. 2015. The effect of phosphorus on yield and yield components of green bean. J. soil nature, 8(1):9-13.

Raghothama, K.G. \& Karthikeyan, A.S. 2005. Phosphate acquisition. Plant and soil, 274: 37- 49. Response of soybean (Glycine $\max$ L.) to sulfur and phosphorus. Indian Society of Soil Science Journal, 28:189- 192.

Rob, N., Mikkelsen, R. \& Jensen, T. 2013. Better crops with plant food. A Publication of the International Plant Nutrition Institute series on sulfur nutrition No. 2.

Sabreen, K.H., Mansour, H.A., El-Hady, M.A. \& Ebtisam, I.E. 2014. Maximize utilization from fertigation management for snap bean (Phaseolus vulgaris L.) under sandy soil. IOSR-JAVS, 7, 1-6.

Singh, S. \& Kapoor, K. 1994. Solubilization of insoluble phosphate by bacteria isolated from different sources. Environ. Ecol. 12, 51-55.

Singh, Y.P. \& Aggarwal, R.L. 1998. Effect of sulfur and levels on yield, nutrient uptake and quality of black gram (Phaseolus mungo). Indian Journal of Agronomy, 43:448-452.

Taha, A.A., Ibrahim A.A. \& Abdel, H. 2011. Irrigation scheduling for pea using evaporation pan under drip irrigation at north Nile delta region. J. Soil Sci. and Agric. Eng.2(2): 203-212.

Tesfaye Wossen. 2017. Determination of optimum rate of blended fertilizer for pod yield of snapbean (Pharsalus vulgaris L.) at Teda, North Gondar, Ethiopia. IJSBAR 32(2):66-79.

Walker, W.R. 1989. Guidelines for designing and evaluating surface irrigation system. Irrigation and Drainage Paper $N^{0} .45$, FAO, Rome. 